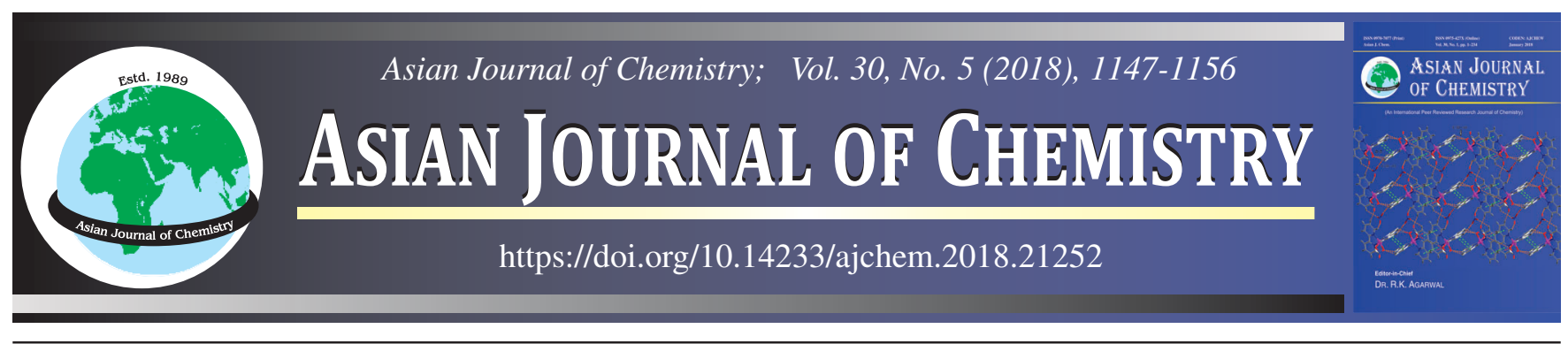

\title{
Contribution to Modelling the Effect of Temperature on Removal of Nickel Ions by Adsorption on Nano-Bentonite
}

\author{
F. Alakhras ${ }^{1, *}$, E. Al-AbBad ${ }^{1}$, N.O. Alzamel ${ }^{1}$, F.M. AbouZeid ${ }^{1,2}$ and N. OuerFelli ${ }^{1}$
}

${ }^{1}$ Department of Chemistry, College of Science, Imam Abdulrahman Bin Faisal University, P.O. Box 1982, Dammam 31441, Saudi Arabia ${ }^{2}$ Chemistry Department, Faculty of Science, Alexandria University, PO Box 2, Moharram Beck, Alexandria 21568, Egypt

*Corresponding author: E-mail: falakhras@iau.edu.sa

\begin{abstract}
Nano-bentonite was investigated as a prospect sorbent for the elimination of nickel ions from aqueous solutions. At optimum conditions $\mathrm{pH} 6, \mathrm{Ni}$ (II) primary concentration $100 \mathrm{mg} / \mathrm{L}$ and adsorbent dosage $0.5 \mathrm{~g}$, the achieved highest adsorption capability was $39.06 \mathrm{mg} / \mathrm{g}$. The isothermal data were modeled with Langmuir and Freundlich isotherm models. Thermodynamic data revealed the spontaneity of target species adsorption onto used adsorbent, raise in entropy change at the solid-liquid boundary and endothermic process. The purpose of this study was to extend primary and secondary prototypes to express the effect of temperature (from 20 to $50{ }^{\circ} \mathrm{C}$ ) on the sorption of nickel ions onto bentonite surface. Proposed models could be integrated to suggest some practical equations for different experimental conditions and can be exploited for further prediction and interesting additional interpretations.
\end{abstract}

Keywords: Nano bentonite, Nickel, Adsorption, Temperature effect, Thermodynamic.

\section{INTRODUCTION}

People in everywhere in the planet have rewarded awareness to the infectivity of exterior and subsurface water initiated by toxic species, due to their huge danger to the accessibility of clean water supplies [1]. The harmfulness of toxic metals is endless and relaxed to accrue in the human being, which may cause several illnesses and even death [2]. In terms of the elimination of poison ions, numerous procedures were progresses. For example: chemical precipitation, electro- chemical reduction, ion-exchange, membrane separation and adsorption [3-8]. Nevertheless, these methods have some difficulties for wide range of applications. Sorption can be realized as a capable technique for heavy metal ions exclusion due to the features of high adsorption capability, easy process, low running charge and green character [9].

Nickel can be considered as one of the poisonous ion species liberated into the surroundings at remarkably high scales via releasing of waste effluents from electroplating, mining and battery manufacturing. Nickel metal can be utilized in producing of stainless steel, non-ferrous alloys and Ni-based super alloys with remarkable anticorrosion and heat resistance features [9]. Some nickel-based materials are also exploited as resourceful catalysts in diverse syntheses [10]. Nickel-oxide and hydroxide are extensively employed in nickel-based rechargeable batteries [11].

The broad reach submission of nickel-based materials occasionally directs to ecological infectivity by $\mathrm{Ni}^{2+}$ and its secondary outputs [12]. Contact to extremely nickel-polluted surroundings has the probable to harvest a multiplicity of obsessive possessions in individuals altering from contact dermatitis to lung fibrosis, cardiovascular and kidney diseases and even cancer $[13,14]$.

In recent times, tender of units with nano-scale level for the elimination of contaminants has arisen as an inspiring domain of study. The exceptional features of nano-sorbents are offering extraordinary chances for the elimination of toxic ions in exceedingly effectual and charge-operative methods and numerous nanoparticles and dendrimers have been utilized for this drive. Nano size bentonite outstandingly offered a more cost proficient effluent management technology because of superior exterior vicinity and superior vigorous sites for bonding with metallic species functional groups [15-18].

In present work, we try to model the effect of temperature on the adsorption of $\mathrm{Ni}$ (II) ions onto nano-bentonite at studied conditions; $\mathrm{pH}$ 6, initial $\mathrm{Ni}(\mathrm{II})$ concentration $50 \mathrm{mg} / \mathrm{L}$ and adsorbent dosage $0.2 \mathrm{~g}$. The suggested semi-empirical equations will permit more interpretation of the studied phenomenon 
and can lead to predict or estimate some quantities when other are available in literature, or estimate different properties values when parameters of experimental conditions are modified, etc. Moreover, the present study comes into general scope of modelling some physico-chemical quantities in order to test the obtained correlation on other experimental conditions and to what extent it can be generalized. Also, the new obtained optimal adjustable parameters can be utilized as a diagnostic or criterion factors in certain practical usages.

\section{EXPERIMENTAL}

Adsorbent: The nano-clay, hydrophilic bentonite, was acquired from Sigma-Aldrich chemie $\mathrm{GmbH}$, with relative density of $2.400 \mathrm{~g} / \mathrm{cm}^{3}$ and $\mathrm{pH}$ of 6-9. The nanobentonite was kept in poly propylene bottle for another exploit.

Characterization: Transmission electron microscopy (TEM), provided particle size ranged from $9.80-12.6 \mathrm{~nm}$ as shown in previous work [1].

Preparation of adsorbate: Stock solution $(1000 \mathrm{mg} / \mathrm{L})$ of $\mathrm{Ni}(\mathrm{II})$ was prepared by dissolving $\mathrm{NiSO}_{4} \cdot 6 \mathrm{H}_{2} \mathrm{O}$ in deionized water. Working solutions were prepared by diluting with deionized water and $\mathrm{pH}$ adjustment using $0.1 \mathrm{M} \mathrm{HCl}$ and 0.1 $\mathrm{M} \mathrm{NaOH}$ solution. New prepared working solutions were used for each trial.

Adsorption method: All investigational tools and glassware were immersed in acid solution $\left[\mathrm{HNO}_{3}(10 \% \mathrm{v} / \mathrm{v})\right]$ for $24 \mathrm{~h}$, washed carefully with tap water, then washed with 3-4 portions of deionized water. Subsequently, sorption trials were performed by mixing of target solutions with nano-bentonite kept in flask and shacked using thermostated magnetic agitator for $45 \mathrm{~min}$. The shakeup rapidity $(250 \mathrm{rpm})$ was reserved invariable for all trials to make certain identical combination. Subsequent to achievement of certain stirring period, the solutions were discarded at $12000 \mathrm{rpm}$ and the fluid in every vial was diluted, while residual amount of nickel ions was determined using atomic absorption spectrophotometer, AAS, (Perkin Elmer Analyst 300). All experimental details are mentioned in previous work [1].

Effect of temperature: The Ni(II) solution $(250 \mathrm{~mL}$, $50 \mathrm{mg} / \mathrm{L}$ ) whiskered with $0.2 \mathrm{~g}$ of sorbent for agitation period of $45 \mathrm{~min}$ at different temperatures $(293.15,303.15,313.15$ and $323.15 \mathrm{~K})$ and agitation speed $(250 \mathrm{rpm})$ at atmospheric pressure. Also, the $\mathrm{pH}$ of solution is 6 .

Effect of primary concentration: The sorption trials were performed by shaking $250 \mathrm{~mL}$ of investigated metal solutions $(\mathrm{pH} 6)$ with $0.2 \mathrm{~g}$ of nano-bentonite for agitation period of 45 $\min$. The primary concentrations $10,20,30,40$ and $50 \mathrm{mg} / \mathrm{L}$, temperature $(303 \mathrm{~K})$ and shake up rate $(250 \mathrm{rpm})$.

Data analysis: The experimental data were used to calculate the Ni(II) \% removal in accordance with the following equation:

$$
\text { Removal }(\%)=\frac{\mathrm{C}_{\mathrm{o}}-\mathrm{C}_{\mathrm{t}}}{\mathrm{C}_{\mathrm{o}}} \times 100
$$

where $\mathrm{C}_{\mathrm{o}}(\mathrm{mg} / \mathrm{L})$ is the initial $\mathrm{Ni}(\mathrm{II})$ concentration while $\mathrm{C}_{\mathrm{t}}$ $(\mathrm{mg} / \mathrm{L})$ is the $\mathrm{Ni}(\mathrm{II})$ concentration at time t. The adsorption capacity, the amount of metal ions adsorbed per mass-unit of the adsorbent, was determined using the following equations:

(i) The adsorption capacity at time $\mathrm{t}, \mathrm{q}_{\mathrm{t}}(\mathrm{mg} / \mathrm{g})$ :

$$
\mathrm{q}_{\mathrm{t}, \mathrm{T}}(\mathrm{t})=\frac{\left(\mathrm{C}_{\mathrm{o}}-\mathrm{C}_{\mathrm{t}, \mathrm{T}}(\mathrm{t})\right) \mathrm{V}}{\mathrm{m}}
$$

(ii) The adsorption capacity at equilibrium, $\mathrm{q}_{\mathrm{e}}(\mathrm{mg} / \mathrm{g})$ :

$$
\mathrm{q}_{\mathrm{e}, \mathrm{T}}=\frac{\left(\mathrm{C}_{\mathrm{o}}-\mathrm{C}_{\mathrm{t}, \mathrm{T}}\right) \mathrm{V}}{\mathrm{m}}
$$

where $C_{e}(m g / L)$ is the equilibrium concentration of metal ions, $\mathrm{m}(\mathrm{g})$ is the mass of adsorbent and $\mathrm{V}(\mathrm{L})$ is the volume of metal solution.

\section{RESULTS AND DISCUSSION}

Effect of temperature on $\mathrm{Ni}(\mathrm{II})$ concentration: Starting from the experimental data of $\mathrm{Ni}(\mathrm{II})$ concentration $\mathrm{C}_{\mathrm{t}, \mathrm{T}}(\mathrm{t})$ with time (t) at different fixed temperature $\mathrm{T}$ (from 20 to 50$)^{\circ} \mathrm{C}$ obtained from previous work [1], Fig. 1 showed variation for each given temperature $(\mathrm{T})$. Note, the experimental data are obtained according to the following conditions: $\mathrm{Ni}$ (II) ions on top of nano-bentonite $\left(250 \mathrm{rpm}, \mathrm{pH}=6, \mathrm{C}_{0}=48.7 \mathrm{mg} / \mathrm{L}\right.$ and $0.2 \mathrm{~g}$ of sorbent). In the previous work, the equilibrium value $\left(\mathrm{C}_{\mathrm{e}}\right)_{\exp }$ has been chosen as the last obtained value at final experimental time $\mathrm{t}_{\mathrm{f}}=45 \mathrm{~min}$ (Table-1), since the $\mathrm{C}_{\mathrm{t}}$-values became practically constant (Fig. 1).

Contact time influence was studied in the range of 0-90 min using nano-bentonite, it was observed that adsorption process was extremely rapid firstly and the equilibrium was accomplished in $45 \mathrm{~min}$. The sorption was incredibly rapid between 1-30 min, decelerated subsequent to $30 \mathrm{~min}$ and reached balance in $45 \mathrm{~min}$. Additional raise in agitation interval did not improve Ni(II) removal. The sluggish removal speed at the final phase may be referred to the complexity faced by $\mathrm{Ni}$ (II) ions to reside in the residual empty vigorous sites and intra particle diffusion method. This performance of sorption

TABLE-1

Ni(II) CONCENTRATION AT EQUILIBRIUM $\left(\mathrm{C}_{\mathrm{e} . \mathrm{T}}\right)$ WITH TEMPERATURE $(\mathrm{T})$ AND OPTIMAL PARAMETERS VALUES OF EQNS. 4 AND 5 WITH THE CORRESPONDING CORRELATION COEFFICIENT (R)

\begin{tabular}{ccccccccc}
\hline $\mathrm{T}(\mathrm{K})$ & $\mathrm{C}_{\mathrm{e}, \text { ex }}(\mathrm{mg} / \mathrm{L})$ & $\mathrm{t}(\mathrm{min})$ & $\mathrm{a}(\mathrm{mg} / \mathrm{L} . \mathrm{K})$ & $\mathrm{b}(\mathrm{mg} / \mathrm{L})$ & $\mathrm{R}$ & $\mathrm{a}\left(10^{-3} \mathrm{mg} . \mathrm{K} / \mathrm{L}\right)$ & $\mathrm{b}(\mathrm{mg} / \mathrm{L})$ & $\mathrm{R}$ \\
\hline \multirow{2}{*}{293.15} & \multirow{2}{*}{12.02} & 0.0 & 0.0000 & 48.700 & - & 0.0000 & 48.700 & - \\
& & 1.0 & 0.25246 & 107.39 & 0.9997 & 23.914 & 65.106 & 0.9998 \\
\hline \multirow{2}{*}{303.15} & \multirow{2}{*}{10.18} & 3.0 & 0.29672 & 111.00 & 0.9993 & 21.119 & 70.349 & 0.9991 \\
& & 5.0 & 0.29602 & 110.14 & 0.9988 & 27.452 & 71.483 & 0.9977 \\
\hline \multirow{2}{*}{313.15} & \multirow{2}{*}{8.89} & 10.0 & 0.28082 & 100.37 & 0.9994 & 26.560 & 71.267 & 0.9980 \\
& & 15.0 & 0.24121 & 86.083 & 0.9989 & 22.804 & 69.347 & 0.9970 \\
\hline \multirow{2}{*}{323.15} & \multirow{2}{*}{7.22} & 30.0 & 0.18097 & 66.040 & 0.9996 & 17.143 & 45.432 & 0.9997 \\
& & 45.0 & 0.16012 & 59.001 & 0.9998 & 15.150 & 39.569 & 0.9987 \\
\hline
\end{tabular}




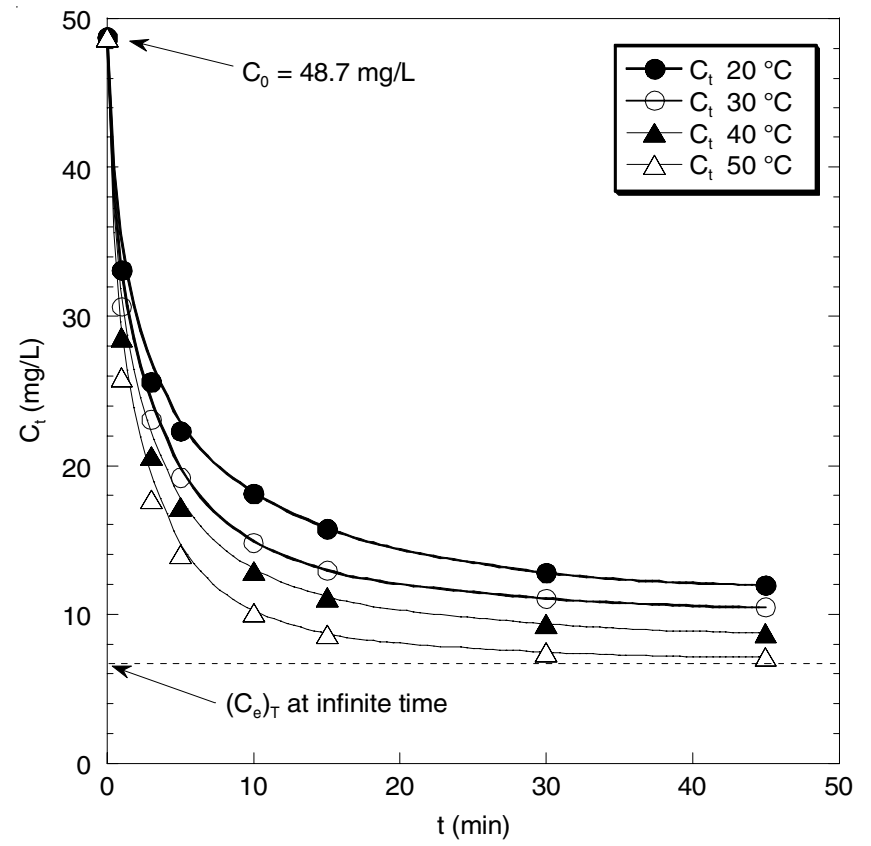

Fig. 1. Variation of $\mathrm{Ni}(\mathrm{II})$ concentration $\mathrm{C}_{\mathrm{t} . \mathrm{T}}(\mathrm{t})$ with time (from 0 to 45 $\min )$ at different given temperature

as a role of agitation time could be clarified according to the active sites fastening capability, repulsion between already occupied sites and upcoming species, in addition to the incline of concentration among adsorbed substance and sorbent gradually. Comparable result has been documented earlier that with the extend of agitation period the removal course decelerated owing to tiredness of dynamic sites with time and variation in inclination concentration of $\mathrm{Ni}(\mathrm{II})$ ions [19].

However, we can examine the effect of temperature by plotting $\mathrm{C}_{\mathrm{t}}$ against temperature $(\mathrm{T})$ at fixed time $\mathrm{t}$, by matrix transposition of the data table of Fig. 1 to be re-plotted in Fig. $2 \mathrm{a}$ and $2 \mathrm{~b}$. We observed that the variation exhibited practically linear behaviour, both versus temperature T (Fig. 2a)
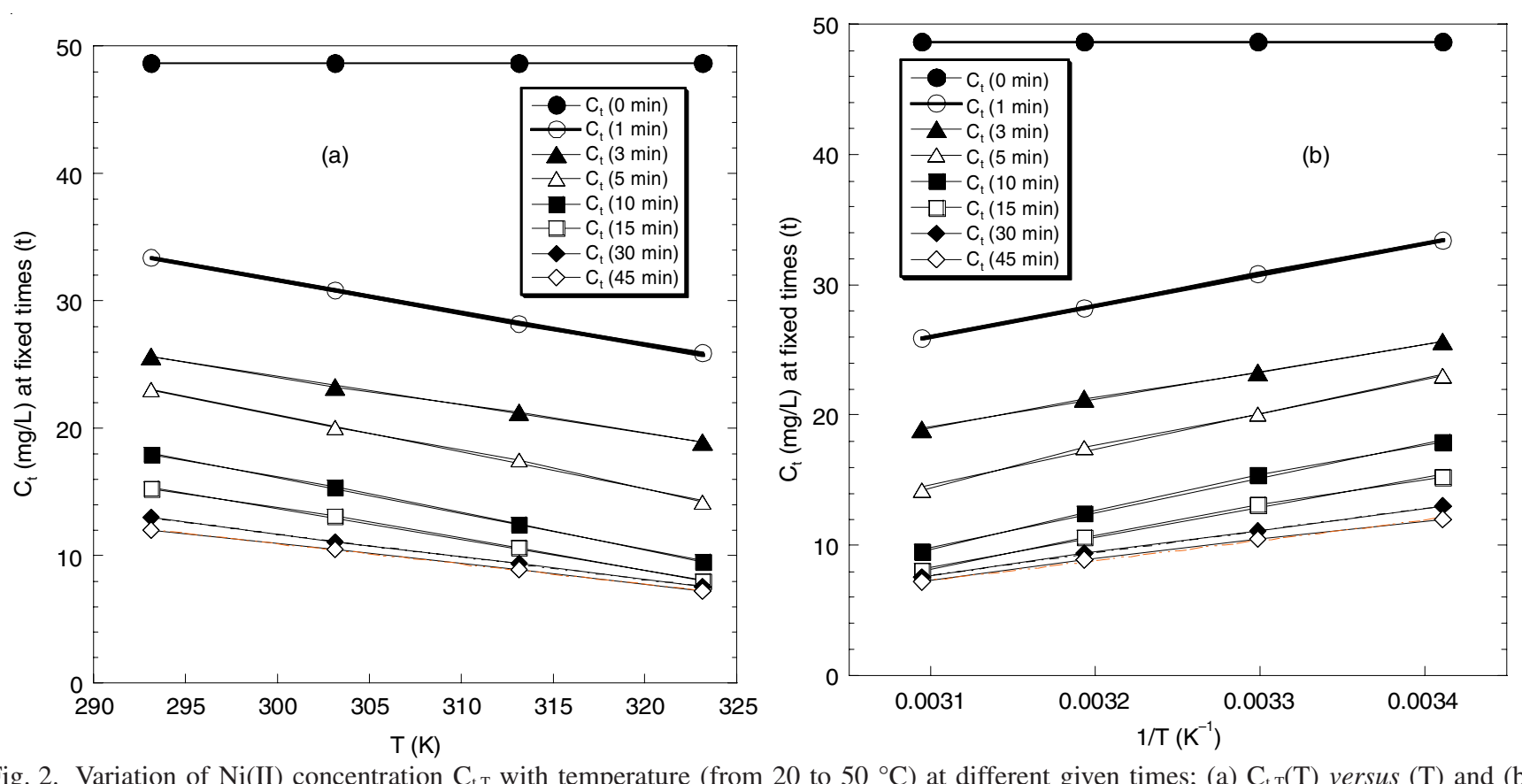

Fig. 2. Variation of $\mathrm{Ni}(\mathrm{II})$ concentration $\mathrm{C}_{\mathrm{t} . \mathrm{T}}$ with temperature (from 20 to $50{ }^{\circ} \mathrm{C}$ ) at different given times; (a) $\mathrm{C}_{\mathrm{t} . \mathrm{T}}(\mathrm{T})$ versus $(\mathrm{T})$ and $(\mathrm{b}$ ) $\mathrm{C}_{\mathrm{t} . \mathrm{T}}(1 / \mathrm{T})$ versus $(1 / \mathrm{T})$ and versus the reciprocal of temperature (Fig. 2b) with a reliable average of correlation coefficient $\mathrm{R}=0.99935$ and 0.99862 , respectively. Through the small difference between the two R-values, it is concluded that the study of the variation of $\mathrm{C}_{\mathrm{t}}(\mathrm{T})$ with temperature $(\mathrm{T})$ is probably more suitable than with $(1 / \mathrm{T})$.

Nevertheless, linear regression on the data of Fig. 2 allowed us to express the variation of the $\mathrm{Ni}(\mathrm{II})$ concentration $\left(\mathrm{C}_{\mathrm{t}, \mathrm{T}}\right)$ with temperature $(\mathrm{T})$ or with its reciprocal one $(1 / \mathrm{T})$ as follows:

$$
\begin{aligned}
& \mathrm{C}_{\mathrm{t}, \mathrm{T}}=-\mathrm{a} \cdot \mathrm{T}+\mathrm{b} \\
& \text { or } \quad \mathrm{C}_{\mathrm{t}, \mathrm{T}}=-\alpha \cdot 1 / \mathrm{T}-\beta
\end{aligned}
$$

where $\mathrm{a}, \mathrm{b}, \alpha$ and $\beta$ are adjustable positive parameters given in Table-1 and plotted in Fig. $3 \mathrm{a}$ and $3 \mathrm{~b}$ as a function of time (t).

It is observed that all these parameters exhibited similar behaviour through times. In fact, their values both started by a rapid increase at initial time to reach a maximum value at time $\mathrm{t} \approx 4.5 \mathrm{~min}$ approximately and then decreased slightly to become constant at infinite time $t_{\infty}$ greater than the final experimental time $\mathrm{t}_{\mathrm{f}}=45 \mathrm{~min}$ (i.e. horizontal asymptote).

Though, the exponential decrease of $\mathrm{C}_{\mathrm{t}, \mathrm{T}}$ with time at different temperature $\mathrm{T}$ (Fig. 1) and the non-constancy of parameter (Fig. 3) at final experimental time $t_{\mathrm{f}}$, suggested that the true limiting $\left(\mathrm{C}_{\mathrm{e}, \mathrm{T}}\right)$ occurred at infinite time $\mathrm{t}_{\infty}$ and not at final time $\left(\mathrm{t}_{\mathrm{f}}=45 \mathrm{~min}\right)$.

So regarding this behaviour, we can suggest exponential form with time as follows:

$$
C_{t, T}(t)=\left(C_{o}-C_{e, T}\right) e^{-f_{T}(T)}+C_{e, T}
$$

where at given temperature $\mathrm{T}, \mathrm{C}_{\mathrm{o}}$ and $\mathrm{C}_{\mathrm{e}, \mathrm{T}}$ are the primary $\mathrm{Ni}$ (II) concentration $(48.7 \mathrm{mg} / \mathrm{L})$ and the equilibrium value respectively and $\mathrm{f}_{\mathrm{T}}(\mathrm{t})$ is the mathematical positive strictly monotone increasing function on time $(\mathrm{t})$, which starts from time zero (Fig. 4) at initial time $(\mathrm{t}=0)$. 

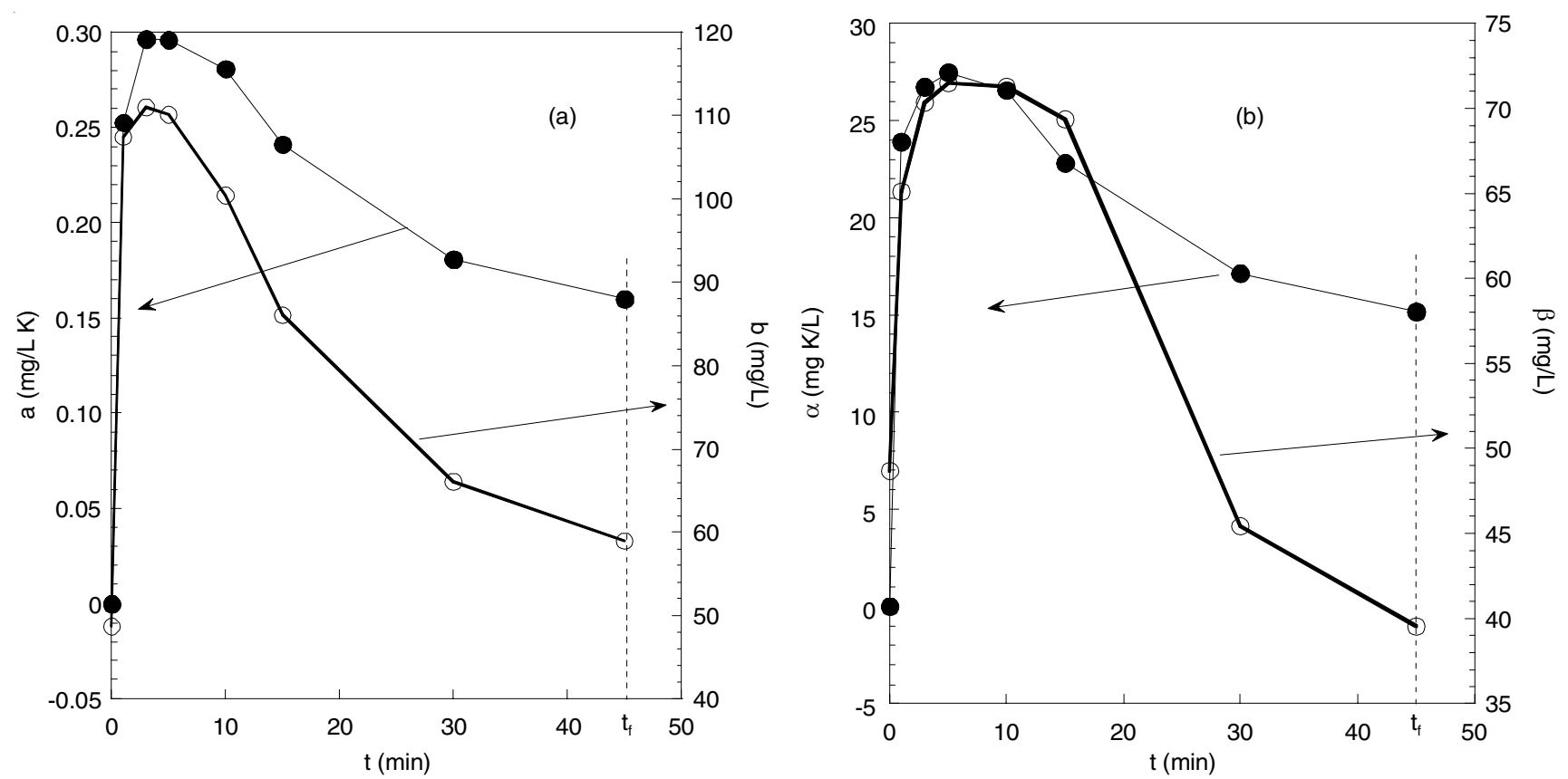

Fig.3. Variation of optimal adjustable parameters of eqns. 4 and 5 with time; $(\bullet)$ the absolute value of slope (a) or $(\alpha)$; (o) the intercept to the ordinate (b) or $(-\beta)$

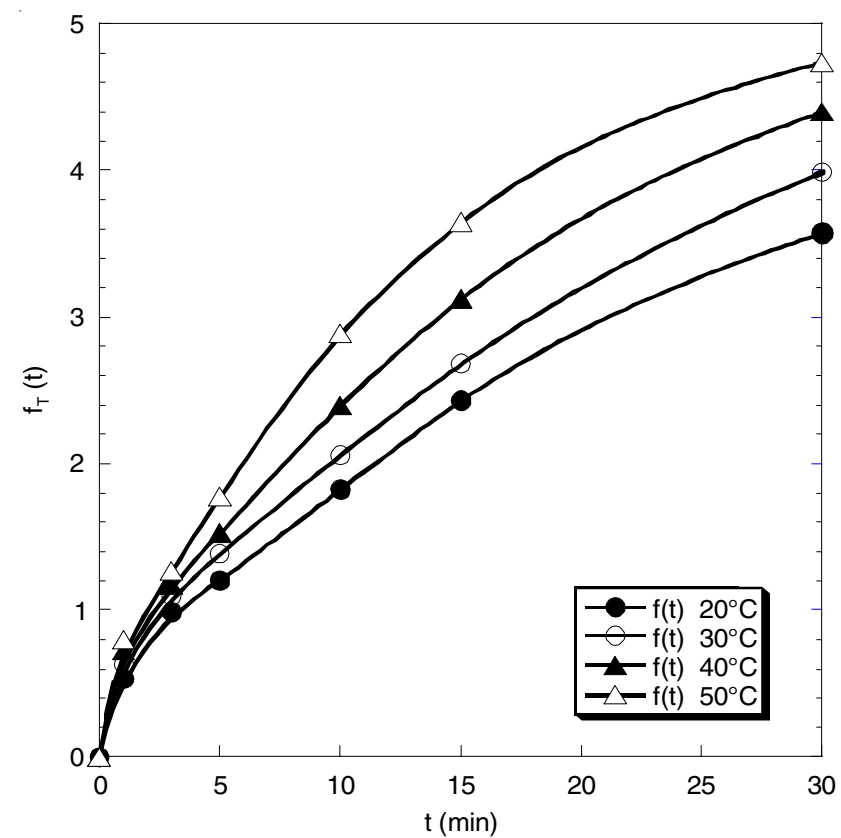

Fig. 4. Variation of the exponent involved in the model of eqn. 6 with time at different fixed temperature

Non-linear regression correlation has given value at limiting concentration value $\left(\mathrm{C}_{\mathrm{e}, \text { cal }}\right)$ which is presented in Table-2 with the percentage deviation (\% dev.) to the adopted experimental value $\left(\mathrm{C}_{\mathrm{e}, \mathrm{exp}}\right)$ according to the previous work [1].

$$
\operatorname{dev} .(\%)=100 \times \frac{\mathrm{C}_{\mathrm{e}, \mathrm{T}, \mathrm{cal}}-\mathrm{C}_{\mathrm{e}, \mathrm{T}, \mathrm{exp}}}{\mathrm{C}_{\mathrm{e}, \mathrm{T}, \mathrm{cal}}}
$$

It is noticed that the deviation is very small and the chosen value $\left(\mathrm{C}_{\mathrm{e}, \text { exp }}\right)$ in previous work is reliable. Nevertheless, for theoretical handling and statistical analysis in modelling, it is more preferable to use the theatrical limiting value $\left(\mathrm{C}_{\mathrm{e}, \mathrm{cal}}\right)$ at infinite time $t_{\infty}$

Moreover, we can preliminarily propose an empirical equation $\left[\mathrm{f}_{\mathrm{T}}(\mathrm{t})=\mathrm{A} \cdot \ln (\mathrm{B} \cdot \mathrm{t}+1)\right]$ which can well fit the experimental values of $f_{T}(t)$ and, $(A>1)$ and $(B<1)$ are two positive adjustable free parameters depending on temperature. In future, more investigations will be forwarded toward the kinetic part.

For this purpose, we can suggest a limiting "true" value of some derived properties such as the adsorption capacity at equilibrium $\left(\mathrm{q}_{\mathrm{e}, \text { cal }}\right)$ which most exhibited the same behaviour with $\mathrm{Ni}(\mathrm{II})$ concentration $\mathrm{C}_{\mathrm{t}}$ (Fig. 5) due to mutual linear dependence expressed by eqn. 2 at time $t$ and by eqn. 3 .

It is noted that due to linear dependence, we can give an expression for $\mathrm{q}_{\mathrm{T}}(\mathrm{t})$ as follows :

$$
\mathrm{q}_{\mathrm{t}, \mathrm{T}}(\mathrm{t})=\mathrm{q}_{\mathrm{e}, \mathrm{T}}\left(1-\mathrm{e}^{-\mathrm{f}_{\mathrm{T}}(\mathrm{t})}\right)
$$

TABLE-2

EXPERIMENTAL AND CALCULATED VALUES AT EQUILIBRIUM (FOR DIFFERENT TEMPERATURES) OF Ni(II) CONCENTRATION $\left(\mathrm{C}_{\mathrm{eT}}\right)$, THE ADSORPTION CAPACITY $\left(\mathrm{q}_{\mathrm{eT}}\right)$ AND THE EQUILIBRIUM, CONSTANT $\mathrm{K}_{\mathrm{T}}^{\circ}$ AND THEIR CORRESPONDING PERCENTAGE DEVIATION TO THE ADOPTED EXPERIMENTAL VALUES [Ref. 1]

\begin{tabular}{cccc|ccc|ccc}
\hline \multirow{2}{*}{$\mathrm{T}(\mathrm{K})$} & \multicolumn{3}{c}{$\mathrm{C}_{\mathrm{e}}(\mathrm{mg} / \mathrm{L})$} & \multicolumn{3}{c|}{$\mathrm{q}_{\mathrm{e}}(\mathrm{mg} / \mathrm{g})}$. & \multicolumn{2}{c}{$\mathrm{K}^{\circ}=\mathrm{q}_{\mathrm{e}} / \mathrm{C}_{\mathrm{e}}$} \\
\cline { 2 - 9 } & Exp. & Cal. & Dev. $(\%)$ & Exp. & Cal. & Dev. $(\%)$ & Exp. & Cal. & Dev. $(\%)$ \\
\hline 293.15 & 12.02 & 11.946 & -0.61 & 18.33 & 18.377 & 0.26 & 1.5250 & 1.5383 & 0.87246 \\
303.15 & 10.18 & 10.500 & 3.14 & 18.94 & 19.100 & 0.85 & 1.8605 & 1.8191 & -2.2258 \\
313.15 & 8.89 & 8.7202 & -1.91 & 19.90 & 19.990 & 0.45 & 2.2385 & 2.2924 & 2.4061 \\
323.15 & 7.22 & 7.1003 & -1.66 & 20.74 & 20.800 & 0.29 & 2.8726 & 2.9294 & 1.9779 \\
\hline
\end{tabular}




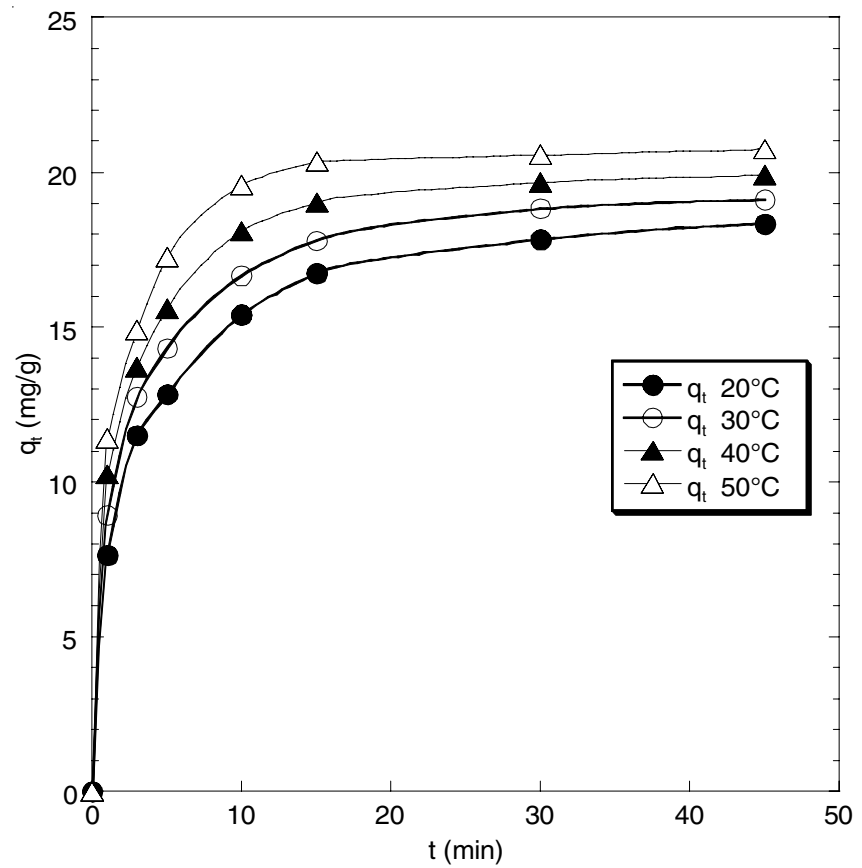

Fig. 5. Variation of the adsorption capacity $\left(\mathrm{q}_{\mathrm{t}, \mathrm{T}}\right)$ with time (from 0 to 45 min) at different given temperature

where $\mathrm{f}_{\mathrm{T}}(\mathrm{t})$ is the same function defined in eqn. 6 and shown in Fig. 4. The obtained calculated values $\left(\mathrm{q}_{\mathrm{e}, \mathrm{T}, \mathrm{cal}}\right)$ are presented in Table- 2 with the corresponding percentage deviation $(\%$ Dev.) to the adopted experimental value ( $\left.\mathrm{q}_{\mathrm{e}, \mathrm{T}, \mathrm{exp}}\right)$ [1] and calculated using the following equation (Table-2):

$$
\operatorname{dev} .(\%)=100 \times \frac{\mathrm{q}_{\mathrm{e}, \mathrm{T}, \mathrm{cal}}-\mathrm{q}_{\mathrm{e}, \mathrm{T}, \exp }}{\mathrm{q}_{\mathrm{e}, \mathrm{T}, \mathrm{cal}}}
$$

It is concluded that this double temperature $(\mathrm{T})$ and time (t) dependence on $\mathrm{Ni}(\mathrm{II})$ concentration $\left(\mathrm{C}_{\mathrm{t}, \mathrm{T}}\right)$ can be guided to provide an explicit global function of $\mathrm{T}$ and $\mathrm{t}$ for which the corresponding parameter becomes an excellent specific experimental conditions' indicator with eventual physical meanings. Also, it could be an interesting comparison between the obtained parameters' values for different experimental conditions.

Thermodynamic parameters-temperature dependence for the adsorption on $\mathrm{Ni}$ (II) onto nano-bentonite at equilibrium: Through the equilibrium data presented in Table- 2 for $\mathrm{Ni}(\mathrm{II})$ concentration $\left(\mathrm{C}_{\mathrm{e}, \mathrm{T}}\right)$ and the sorption capability $\left(\mathrm{q}_{\mathrm{e}, \mathrm{T}}\right)$ at different temperatures, we can deduce the equilibrium constant $\left(\mathrm{K}_{\mathrm{T}}^{\circ}\right)$ of adsorption reaction which can be calculated as follows:

$$
\mathrm{K}_{\mathrm{T}}^{\mathrm{o}}=\frac{\mathrm{q}_{\mathrm{e}, \mathrm{T}}}{\mathrm{C}_{\mathrm{e}, \mathrm{T}}}
$$

where $\mathrm{K}_{\mathrm{T}}^{\circ}$ is a distribution constant $(\mathrm{L} / \mathrm{g})$ at the absolute temperature $\mathrm{T}$ (Table-2) which is applied to calculate the Gibbs free energy $\left(\Delta \mathrm{G}_{\mathrm{T}}^{\circ}\right)$ using the following expression:

$$
\Delta \mathrm{G}_{\mathrm{T}}^{\circ}=-\mathrm{RT} \ln \mathrm{K}_{\mathrm{T}}^{\circ}
$$

where $\mathrm{R}$ is the perfect gas constant. The enthalpy change $\left(\Delta \mathrm{H}^{\circ}\right)$ and entropy change $\left(\Delta S^{\circ}\right)$ can be related to the Gibbs free energy $\left(\Delta \mathrm{G}^{\circ}{ }_{\mathrm{T}}\right)$ as a follows:

$$
\Delta \mathrm{G}_{\mathrm{T}}^{\circ}=\Delta \mathrm{H}^{\circ}-\mathrm{T} \Delta \mathrm{S}^{\circ}
$$

and it can be determined graphically by plotting of $\left(\Delta \mathrm{G}^{\circ} / \mathrm{T}\right)$ as a function of reciprocal of temperature $(1 / \mathrm{T})$ as shown by Fig. 6.

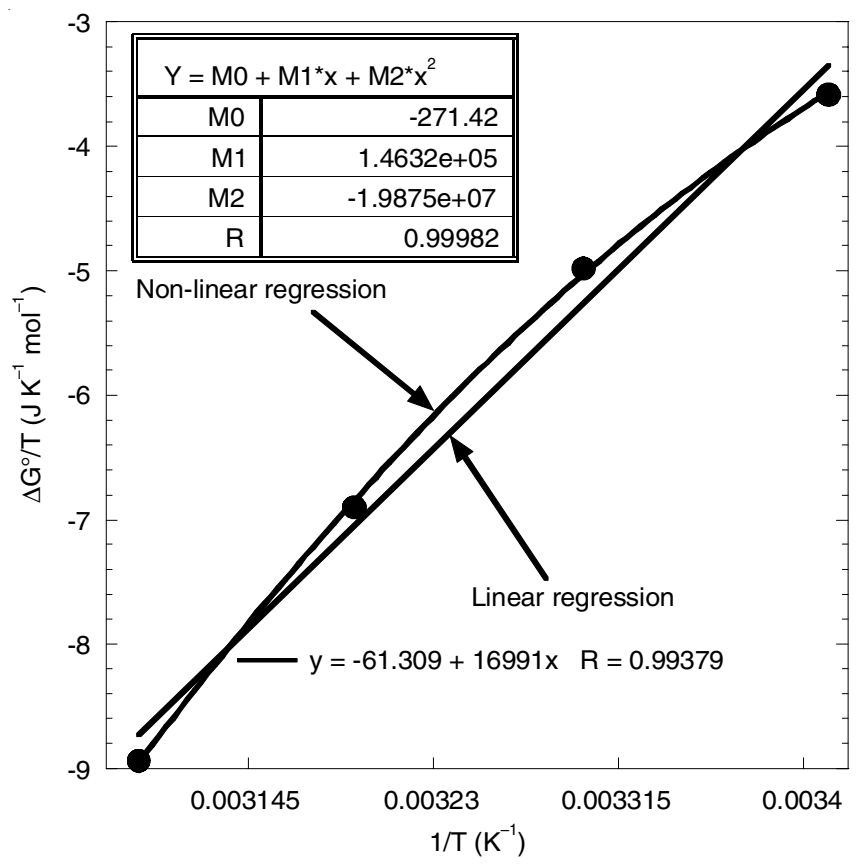

Fig. 6. Variation of the ratio $\left(\Delta \mathrm{G}^{\circ} / \mathrm{T}=-\mathrm{R} \ln \mathrm{K}_{\mathrm{T}}^{\circ}\right)$ for the adsorption reaction versus the reciprocal absolute temperature (1/T) in the range (293.15 to 323.15) K. The straight line is for linear regression and the curved line is for the non linear regression (two degree polynomial)

By assuming that the two thermodynamic parameters $\Delta \mathrm{H}^{\circ}$ and $\Delta \mathrm{S}^{\circ}$ are practically constant and independent of temperature $\mathrm{T}$, we can determine their values by linear regression with a correlation coefficient $\mathrm{R}_{1}=0.99379$. We found $\Delta \mathrm{H}^{\circ}$ $=16.991 \mathrm{~kJ} \mathrm{~mol}^{-1}$ and $\Delta \mathrm{S}^{\circ}=61.309 \mathrm{~J} \mathrm{~K}^{-1} \mathrm{~mol}^{-1}$ as shown in Table-3.

\section{TABLE-3}

THERMODYNAMIC PARAMETERS FOR THE ADSORPTION OF Ni(II) ONTO NANO-BENTONITE OBTAINED BY LINEAR AND NON-LINEAR REGRESSION AND THE RATIO $\mathrm{T}_{\mathrm{r}}(\mathrm{T})=$ $\Delta H^{\circ}(\mathrm{T}) / \Delta \mathrm{S}^{\circ}(\mathrm{T})(\mathrm{K})$ IN DIFFERENT TEMPERATURES

\begin{tabular}{ccccc}
\hline $\mathrm{T}(\mathrm{K})$ & $\begin{array}{c}\Delta \mathrm{G}^{\circ} \\
(\mathrm{kJ} / \mathrm{mol})\end{array}$ & $\begin{array}{c}\Delta \mathrm{H}^{\circ} \\
(\mathrm{kJ} / \mathrm{mol})\end{array}$ & $\begin{array}{c}\Delta \mathrm{S}^{\circ} \\
(\mathrm{J} / \mathrm{mol} . \mathrm{K})\end{array}$ & $\mathrm{T}_{\mathrm{r}}(\mathrm{T})(\mathrm{K})$ \\
\hline 293.15 & -1.0497 & 10.724 & 40.162 & 267.01 \\
303.15 & -1.5081 & 15.197 & 55.105 & 275.78 \\
313.15 & -2.1600 & 19.384 & 68.798 & 281.75 \\
323.15 & -2.8878 & 23.312 & 81.077 & 287.53 \\
\hline Mean value & & 17.154 & 61.285 \\
Standard deviation & & 5.4183 & 17.631 \\
Value with linear regression & 16.991 & 61.309 \\
\multicolumn{5}{l}{ Deviation to non-linear regression $(\%)$} \\
\hline
\end{tabular}

Influence of temperature was investigated between 20-50 ${ }^{\circ} \mathrm{C}$ for $\mathrm{Ni}$ (II) removal on top of nano-bentonite. It showed a temperature dependent performance. Sorption records style indicated that elimination enhanced with temperature, which is an indication of endothermic adsorption process onto nanobentonite, improved speed of adsorbate diffusion through the exterior border level to the holes of the sorbent molecules because liquid stickiness decreased with temperature. 
The positive value of enthalpy change $\left(\Delta \mathrm{H}^{\circ}\right)$ suggested the endothermic nature of adsorption $[1,20]$. The entropy change $\left(\Delta \mathrm{S}^{\circ}\right)$ value resembled to a progress in arbitrariness at the adsorbent-fluid boundary and may be substantial changes taken place in the interior arrangement of the sorbent via the sorption of $\mathrm{Ni}(\mathrm{II})$ ions on nano-bentonite $[1,21,22]$.

The mathematical value of $\left(\Delta \mathrm{G}^{\circ}\right)$ declined with the temperature showing that the reaction is spontaneous and more favourable at higher temperature. One possible explanation of endothermicity of heats of adsorption is that the metal ions are well solvated. In order to the metal ions got adsorbed, they have to lose part of their hydration sheath [23].

Nevertheless, regarding the non low values of the standard deviation related to $\Delta \mathrm{H}^{\circ}$ and $\Delta \mathrm{S}^{\circ}$ (Table-3), we reinvestigate the variation of $\Delta \mathrm{G}^{\circ} / \mathrm{T}$ by nonlinear regression and consider that $\Delta \mathrm{H}^{\circ}$ and $\Delta \mathrm{S}^{\circ}$ vary slightly with temperature (T) for which we can fit $\left(\Delta \mathrm{G}^{\circ} / \mathrm{T}\right)$ in a two degree polynomial on $(1 / \mathrm{T})$ with a reliable correlation coefficient $R_{2}=0.99982$ (Fig. 6) which is greater than $\mathrm{R}_{1}$ obtained by linear regression.

From the obtained values of polynomial coefficient (Fig. 6) we can determinate values of $\Delta \mathrm{H}^{\circ}(\mathrm{T})$ and $\Delta \mathrm{S}^{\circ}(\mathrm{T})$ at each temperature $(\mathrm{T})$ using the following thermodynamic expressions at constant pressure $(\mathrm{P})$ :

$$
\begin{gathered}
\Delta H^{\circ}(T)=\left(\frac{\partial\left(\Delta G^{\circ} / T\right)}{\partial(1 / T)}\right)_{P} \\
\Delta S^{\circ}(T)=\left(\frac{\partial\left(\Delta G^{\circ}\right)}{\partial(T)}\right)_{P}
\end{gathered}
$$

It is observed that there is net variation with temperature around a mean value of $17.164 \mathrm{~kJ} \mathrm{~mol}^{-1}$ and $61.285 \mathrm{~J} \mathrm{~K}^{-1} \mathrm{~mol}^{-1}$ (Table-3, Fig. 7) for $\Delta \mathrm{H}^{\circ}(\mathrm{T})$ and $\Delta \mathrm{S}^{\circ}(\mathrm{T})$, respectively with the large standard deviation especially for the entropy change $\Delta \mathrm{S}^{\circ}(\mathrm{T})$. Likewise, we observe that these mean values are very close to $\Delta \mathrm{H}^{\circ}$ and $\Delta \mathrm{S}^{\circ}$ values obtained by linear regression approximation (Table-3).

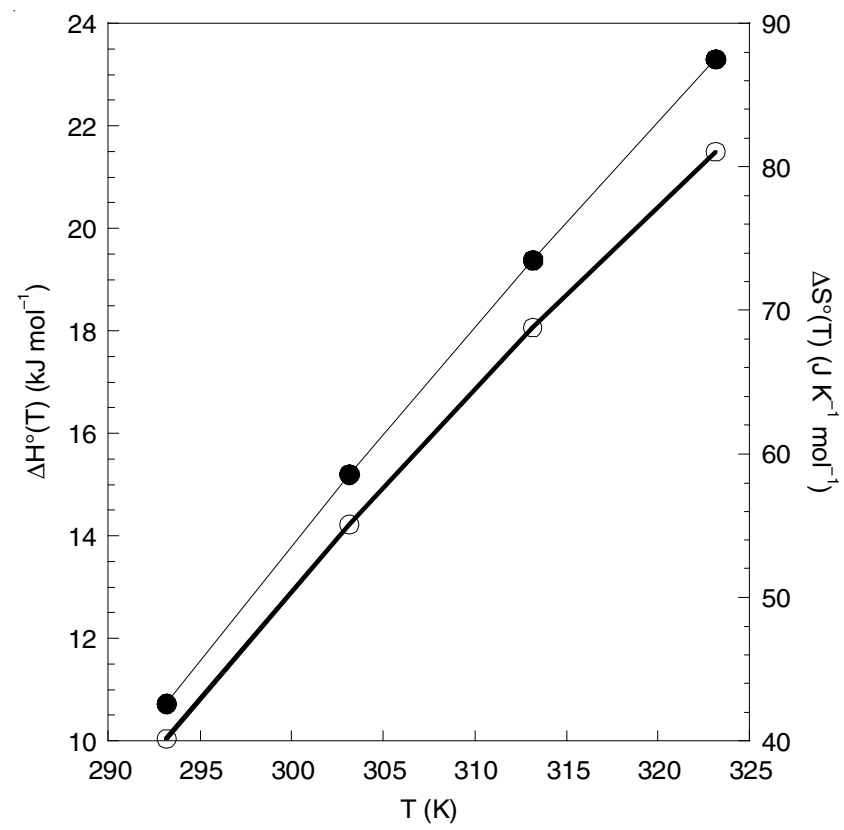

Fig. 7. Variation of the thermodynamic parameters for the adsorption of $\mathrm{Ni}(\mathrm{II})$ onto nano-bentonite obtained by linear and non-linear regression, as a function of temperature; $(\bullet) \Delta \mathrm{H}^{\circ}(\mathrm{T})$ and $(\mathrm{O}) \Delta \mathrm{S}^{\circ}(\mathrm{T})$
In addition, Fig. 7 showed a clear similar behaviour of $\Delta \mathrm{H}^{\circ}(\mathrm{T})$ and $\Delta \mathrm{S}^{\circ}(\mathrm{T})$ against temperature (i.e. increasing and convexity of the curative). This ascertainment indicated about elimination of the variable temperature and the inspection of the variation of $\Delta \mathrm{H}^{\circ}(\mathrm{T})$ versus $\Delta \mathrm{S}^{\circ}(\mathrm{T})$.

Fig. 8 showed an interesting linear dependence between the two parameters $\Delta \mathrm{H}^{\circ}(\mathrm{T})$ and $\Delta \mathrm{S}^{\circ}(\mathrm{T})$ with a good correlation coefficient $\mathrm{R}=0.99989$ and which can be expressed as follows:

$$
\Delta \mathrm{H}^{\circ}(\mathrm{T})=\mathrm{T}_{0}\left[\Delta \mathrm{S}^{\circ}(\mathrm{T})-\Delta \mathrm{S}^{\circ}{ }_{1}\right]
$$

where $\mathrm{T}_{0}=307.29 \mathrm{~K}$ (i.e. $34.14{ }^{\circ} \mathrm{C}$ ) is probably an optimal working temperature and $\left(\Delta S^{\circ}\right)$ is the limiting entropy change for which the phenomenon start to be non-endothermic $\left(\Delta \mathrm{S}^{\circ}{ }_{1}\right.$ $\approx 5.461 \mathrm{~J} \cdot \mathrm{K}^{-1} \cdot \mathrm{mol}^{-1}$ ) where the system doesn't require energy (i.e. $\Delta \mathrm{H}^{\circ}=0$ ).

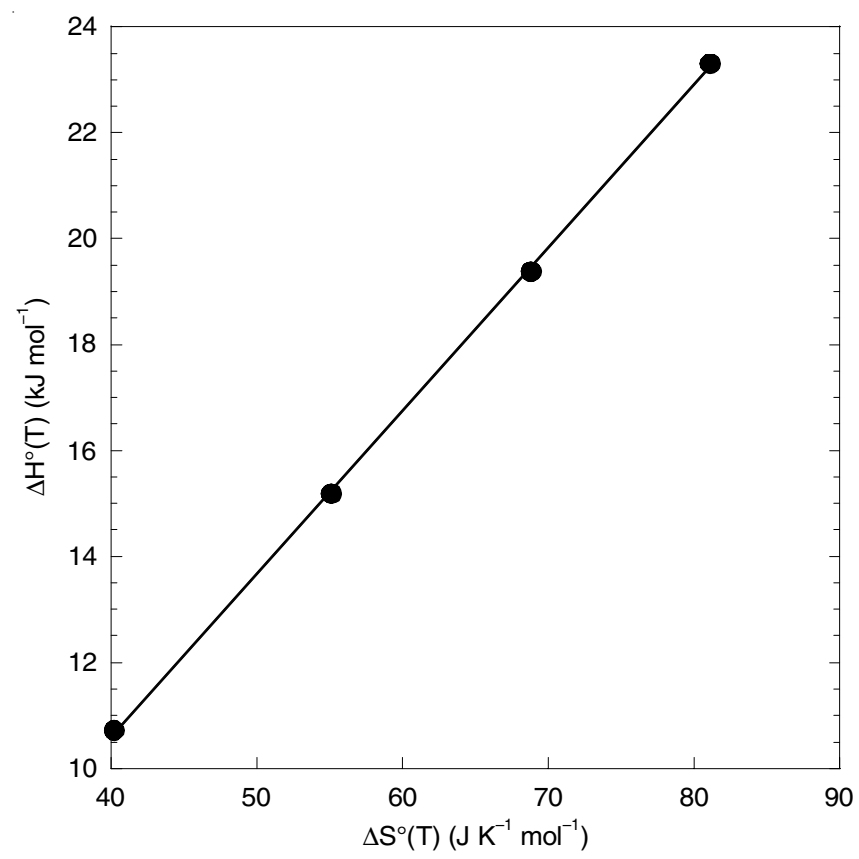

Fig. 8. Mutual correlation between the two thermodynamic parameters for the adsorption of $\mathrm{Ni}(\mathrm{II})$ onto nano-bentonite: $\Delta \mathrm{H}^{\circ}(\mathrm{T})$ versus $\Delta \mathrm{S}^{\circ}(\mathrm{T})$

It is noted that the $\mathrm{T}_{0}$-value is specific for each experimental condition and can be a good interesting criterion for discussion and interpretation when it is linked with different parameters set of experimental conditions.

However, considering the partial derivatives functions of Maxwell equations and the Gibbs free energy expression (eqn. 11), we can consider that $\left(\mathrm{T}_{0}\right)$ can be calculated using the following equation at constant pressure even when the dependence between $\Delta H^{\circ}(T)$ and $\Delta S^{\circ}(T)$ is non linear.

$$
\left(\frac{\partial\left(\Delta \mathrm{H}^{\circ}\right)}{\partial\left(\Delta \mathrm{S}^{\circ}\right)}\right)_{\mathrm{p}}=\mathrm{T}_{0}
$$

On the other hand, to find a single model expressing $\Delta \mathrm{H}^{\circ}(\mathrm{T})$ and $\Delta \mathrm{S}^{\circ}(\mathrm{T})$ with absolute temperature, we have also plotted the ratio $\Delta \mathrm{H}^{\circ}(\mathrm{T}) / \Delta \mathrm{S}^{\circ}(\mathrm{T})$ (Fig. 9) which is equivalent to a temperature and denoted by $\left(\mathrm{T}_{\mathrm{r}}\right)$.

$$
\mathrm{T}_{\mathrm{r}}(\mathrm{T})=\frac{\Delta \mathrm{H}^{\circ}(\mathrm{T})}{\Delta \mathrm{S}^{\circ}(\mathrm{T})}
$$




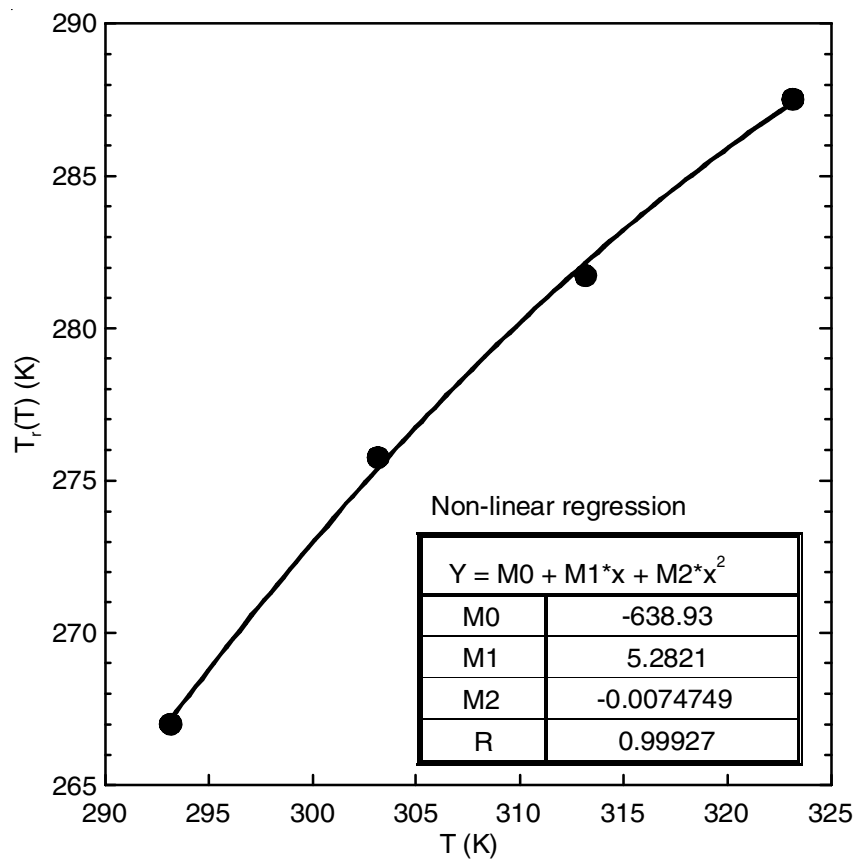

Fig. 9. Variation of the ratio $\mathrm{T}_{\mathrm{r}}(\mathrm{T})=\Delta \mathrm{H}^{\circ}(\mathrm{T}) / \Delta \mathrm{S}^{\circ}(\mathrm{T})(\mathrm{K})$ versus temperature in the studied range (293.15 to 323.15 ) $\mathrm{K}$

Given the quality of regression is equal $(\mathrm{R}=0.99927)$ indicated into Fig. 9 we can be satisfied with the second degree of polynomial and no more. Then, we can suggest the following expression:

$$
\mathrm{T}_{\mathrm{r}}(\mathrm{T})=-\frac{\left(\mathrm{T}-\mathrm{T}_{1}\right)\left(\mathrm{T}-\mathrm{T}_{2}\right)}{\mathrm{T}_{3}}
$$

where $T_{1}, T_{2}$ and $T_{3}$ are adjustable parameters equivalent to temperature, we obtain $\left(\mathrm{T}_{1}=154.93 \mathrm{~K}, \mathrm{~T}_{2}=551.72 \mathrm{~K}\right.$ and $\mathrm{T}_{3}$ $=133.78 \mathrm{~K}$ ) for the studied system at conditions above mentioned. In fact, the coefficient values are dependent on experimental condition and can be interesting parameters for discussion and interpretations when we display a set of data at different temperatures $\mathrm{T}$ for different experimental conditions.

Combining eqns. 15 and 17 we can give an explicit expression of the thermodynamic parameters, specific to the experimental condition indicated in previous work [1] and in experimental section:

$$
\begin{gathered}
\Delta H^{\circ}(T)=\frac{T_{0} \cdot T_{r}(T) \cdot \Delta S_{1}^{o}}{T_{0}-T_{r}(T)} \\
\Delta S^{\circ}(T)=\frac{T_{0} \cdot \Delta S_{1}^{o}}{T_{0}-T_{r}(T)} \\
\Delta G^{\circ}(T)=\frac{T_{0} \cdot\left[T_{r}(T)-T\right] \Delta S_{1}^{o}}{T_{0}-T_{r}(T)}
\end{gathered}
$$

It is noted that all these thermodynamic quantities conserved their sign in the whole studied temperature range because $\left[\mathrm{T}_{\mathrm{r}}(\mathrm{T})<\mathrm{T}\right],\left[\mathrm{T}_{\mathrm{r}}(\mathrm{T})<\mathrm{T}_{0}\right]$ and $\mathrm{T}_{\mathrm{r}}(\mathrm{T})$ reached its maximum value $\left(\mathrm{T}_{\mathrm{r}, \max }=294.22 \mathrm{~K}\right)$ at $\mathrm{T}=353.33 \mathrm{~K}$. We added that $\mathrm{T}_{\mathrm{r}}(\mathrm{T})$ value is somehow an indicator or criterion of the conflict orderdisorder in microscopic scale.

Table-4 summarized possible additional conclusions or interpretations which can be deduced from this new concept of temperature-dependence of thermodynamic functions such as $\Delta \mathrm{G}^{\circ}(\mathrm{T}), \Delta \mathrm{H}^{\circ}(\mathrm{T})$ and $\Delta \mathrm{S}^{\circ}(\mathrm{T})$.

In addition, this new exploration of slight variation of thermodynamic parameters with temperature might open a field of new deep interpretation of the mechanism of the studied processes. Also, the variation of the parameters values from an experiment to another or, from a condition to another can reveal an interesting novel criterion or diagnostic factor, very excellent for discussion, comparison or prediction.

Concentration-temperature dependence for the adsorption on $\mathrm{Ni}$ (II) onto nano-bentonite at equilibrium: The variation at equilibrium of the $\mathrm{Ni}(\mathrm{II})$ concentration $\left(\mathrm{C}_{\mathrm{e}, \mathrm{T}}\right)$ and the sorption ability $\left(\mathrm{q}_{\mathrm{e}, \mathrm{T}}\right)$ with temperature $(\mathrm{T})$ is shown in Fig. 10.

The strictly monotonous variation and feeble curvature can lead us to fit these quantities with only a second degree polynomial with a same reliable correlation coefficient $\mathrm{R}=$ 0.99954 ) in the studied range of temperature (from 293.15 to $323.15 \mathrm{~K}$ ) which can be expressed as follows:

\begin{tabular}{|c|c|c|}
\hline \multicolumn{3}{|c|}{$\begin{array}{c}\text { TABLE-4 } \\
\text { SUMMARY OF THERMODYNAMIC PARAMETERS BEHAVIOUR WITH TEMPERATURE }\end{array}$} \\
\hline & Character & Interpretation \\
\hline$\Delta \mathrm{G}^{\circ}$ & Decreasing negative values & $\begin{array}{l}\text { The reaction is spontaneous and more favourable at higher temperature. The equilibrium of } \\
\text { spontaneous and feasible process is moved to more removal. Also higher temperature to be } \\
\text { favourable for the } \mathrm{Ni}(\mathrm{II}) \text { adsorption. Also confirmed the adsorption process to be physical. The } \\
\text { values for physical adsorption lies between }-20 \text { and } 0 \mathrm{~kJ} / \mathrm{mol} \text { which is smaller than that of } \\
\text { chemical adsorption ranged from }-80 \text { to }-400 \mathrm{~kJ} / \mathrm{mol} \text { [Ref. 24]. }\end{array}$ \\
\hline \multicolumn{3}{|r|}{ Linear regression approximation } \\
\hline$\Delta \mathrm{H}^{\circ}$ & Persistent positive values & The adsorption is endothermic. \\
\hline$\Delta \mathrm{S}^{\circ}$ & Perpetual positive values & $\begin{array}{l}\text { An increase in randomness at the solid-liquid interface and maybe significant changes occur in } \\
\text { the internal structure of the adsorbent through the adsorption of Ni(II) ions on nano-bentonite. }\end{array}$ \\
\hline \multicolumn{3}{|r|}{ Non linear Regression } \\
\hline$\Delta \mathrm{H}^{\circ}$ & Growing positive values & $\begin{array}{l}\text { The adsorption is endothermic. The metal ions are well solvated. In order for the metal ions to be } \\
\text { adsorbed, they have to lose part of their hydration sheath. }\end{array}$ \\
\hline$\Delta S^{\circ}$ & $\begin{array}{l}\text { Intensification positive } \\
\text { values }\end{array}$ & $\begin{array}{l}\text { An increase in randomness at the solid-liquid interface and maybe significant changes occur in } \\
\text { the internal structure of the adsorbent through the adsorption of } \mathrm{Ni}(\mathrm{II}) \text { ions on nano-bentonite. } \\
\text { The temperature accentuates this microscopic disorder. Also reflect favourable condition for the } \\
\text { removal of } \mathrm{Ni}(\mathrm{II}) \text { from synthetic solutions. }\end{array}$ \\
\hline
\end{tabular}

$$
\begin{aligned}
& q_{e, T}=\alpha_{0+} \alpha_{1} T_{+} \alpha_{2} T^{2} \\
& C_{e, T}=\beta_{0+} \beta_{1} T_{+} \beta_{2} T^{2}
\end{aligned}
$$




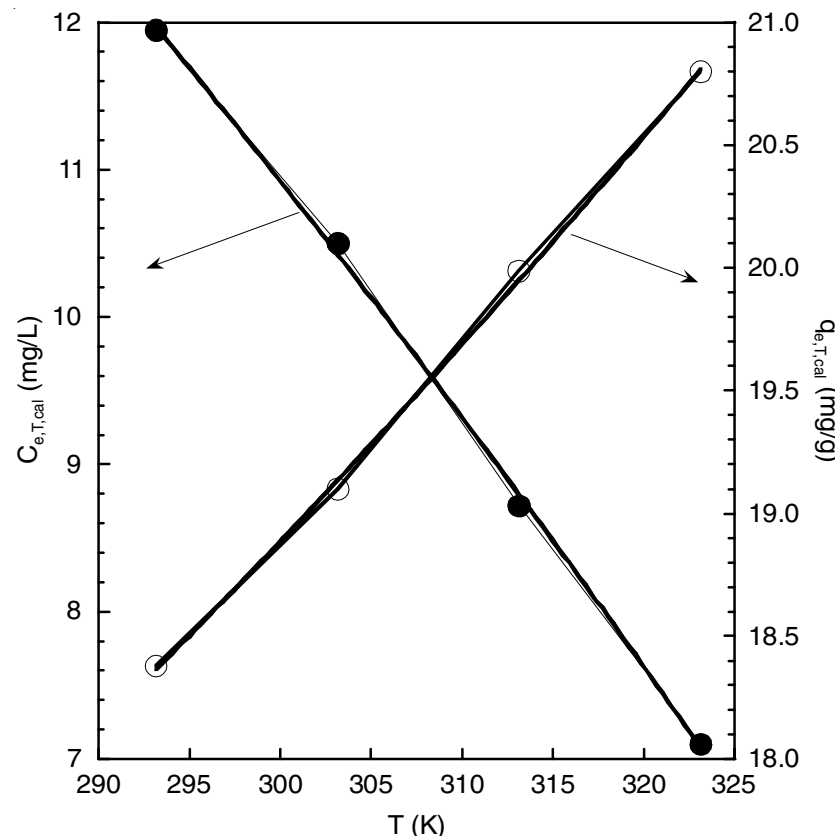

Fig. 10. Variation at equilibrium of $\mathrm{Ni}(\mathrm{II})$ concentration $\left(\mathrm{C}_{\mathrm{e}, \mathrm{T}}\right)$ and the adsorption capacity $\left(\mathrm{q}_{\mathrm{e}, \mathrm{T}}\right)$ against temperature; $(\bullet)$ : $\mathrm{C}_{\mathrm{e}, \mathrm{T}}$ and $(\mathrm{O})$ : $\mathrm{q}_{\mathrm{e}, \mathrm{T}}$

where $\alpha_{i}$ and $\beta_{i}$ are optimal adjustable parameters characterizing the used experimental conditions and also are affected by studied temperature interval. More, the relationship between $\mathrm{C}_{\mathrm{e}, \mathrm{T}}$ and $\mathrm{q}_{\mathrm{e}, \mathrm{T}}$ in eqn. 3 imposed the following experimental conditions:

$$
\beta_{0}=\mathrm{C}_{0}-\frac{\mathrm{m}}{\mathrm{V}} \alpha_{0}
$$

and for $\mathrm{i}=1$ and 2 , we have

$$
\beta_{\mathrm{i}}=-\frac{\mathrm{m}}{\mathrm{V}} \alpha_{\mathrm{i}}
$$

The suggested empirical eqns. 22 and 23 are useful for some experimental data investigation, prediction and estimation magnitudes for other temperatures not far away from the studied temperature range.

Nevertheless, for more large temperature interval, we must use different expression which should be more adequate. In fact, regarding the continue decrease of $\left(\mathrm{C}_{\mathrm{e}, \mathrm{T}}\right)$ and the increase of $\left(\mathrm{q}_{\mathrm{e}, \mathrm{T}}\right)$ against temperature $(\mathrm{T})$, we can expect that the limiting theoretical value of $\left(\mathrm{C}_{\mathrm{e}, \mathrm{T}}\right)_{\lim }=0$ and $\left(\mathrm{q}_{\mathrm{e}, \mathrm{T}}\right)_{\lim }=\mathrm{C}_{0} \mathrm{~V} / \mathrm{m}$ at finite high temperature value or firmly at infinite temperature.

So, $\mathrm{C}_{\mathrm{e}}(\mathrm{T})$ and $\mathrm{q}_{\mathrm{e}}(\mathrm{T})$ functions must exhibit an horizontal asymptotes at very high temperature and we must take this fact into consideration in eventual suggested semi-empirical models which need more experimental data points in more large domain of temperature.

Going to equilibrium constant $\mathrm{K}_{\mathrm{T}}^{\circ}$, we perceive that it can be simply expressed by a second degree polynomial with temperature $(\mathrm{T})$ in the studied range with a good correlation coefficient $R=0.99998$ (Fig. 11).

Nevertheless, for larger domain of temperature, we must take into consideration the precedent boundary conditions which require that the $\mathrm{K}_{\mathrm{T}}^{\circ}$ function exhibit an oblique asymptote at high temperature.

The eqns. 3 and 10 leads us to express $\mathrm{K}^{\circ}{ }_{\mathrm{T}}$ with only one variable $\left(\mathrm{q}_{\mathrm{e}, \mathrm{T}}\right.$ or $\left.\mathrm{C}_{\mathrm{e}, \mathrm{T}}\right)$, as follows:

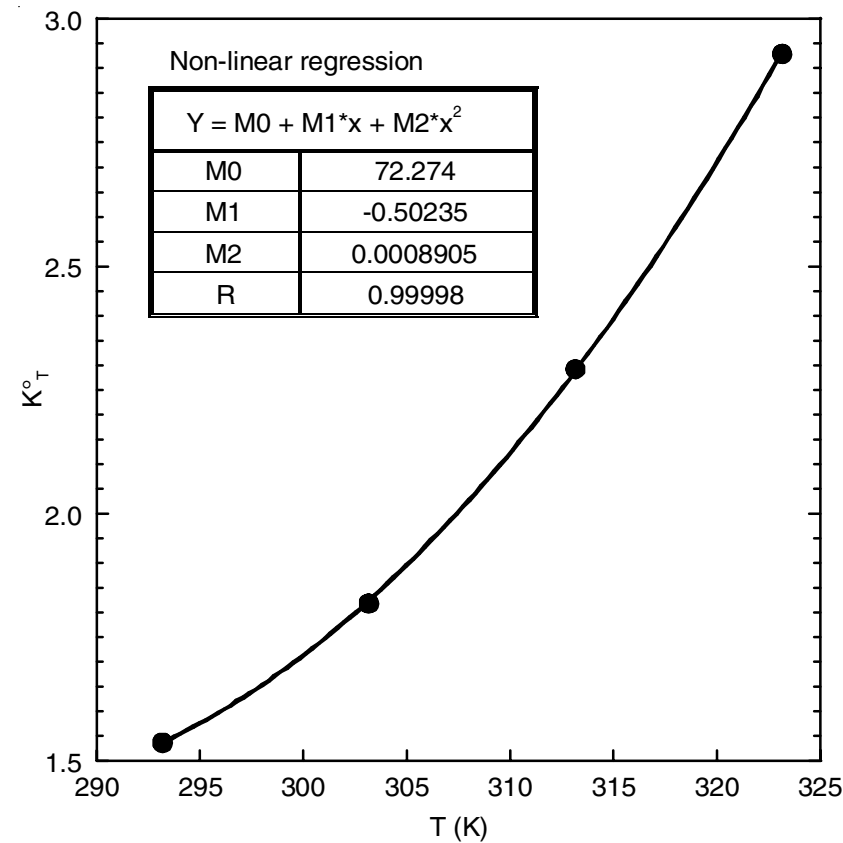

Fig. 11. Variation of the equilibrium constant $\mathrm{K}^{\circ}$ with temperature at atmospheric pressure

$$
\begin{aligned}
\mathrm{K}_{\mathrm{T}}^{0} & =\frac{\mathrm{V} \cdot \mathrm{q}_{\mathrm{e}, \mathrm{T}}}{\mathrm{C}_{0} \cdot \mathrm{V}-\mathrm{m} \cdot \mathrm{q}_{\mathrm{e}, \mathrm{T}}} \\
\mathrm{K}_{\mathrm{T}}^{0} & =\frac{\left(\mathrm{C}_{0}-\mathrm{C}_{\mathrm{e}, \mathrm{T}}\right) \cdot \mathrm{V}}{\mathrm{m} \cdot \mathrm{C}_{\mathrm{e}, \mathrm{T}}}
\end{aligned}
$$

Regarding the strictly monotone increasing feature for the logarithm function and the equation 11, we expect that the reliable suggested expression of the free Gibbs energy $\Delta \mathrm{G}_{\mathrm{T}}^{0}$ must exhibit also an oblique asymptote for large domain of temperature use.

We add that this expected oblique asymptote at high temperature has a straight line's equation which can be expressed as follows:

$$
\mathrm{K}_{\mathrm{T}, \lim }^{\mathrm{o}}=\frac{\mathrm{V}}{\mathrm{m}}\left(\frac{\mathrm{C}_{\mathrm{o}}}{\mu} \cdot \mathrm{T}-1\right)
$$

where

$$
\mu=\lim _{\mathrm{T} \rightarrow \infty}\left(\frac{\partial\left(\mathrm{C}_{\mathrm{o}, \mathrm{T}}\right)}{\partial(1 / \mathrm{T})}\right)_{\mathrm{P}}
$$

Inspecting eqns. $11,12,15-21$, we can write a semi empirical interesting equation as follow:

$$
\mathrm{K}_{\mathrm{T}, \lim }^{\mathrm{o}}=\frac{\mathrm{V}}{\mathrm{m}}\left(\frac{\mathrm{T}}{\mathrm{T}_{\text {lim }}}-1\right)
$$

where $T_{\text {lim }}$ is a limiting temperature in relationship $T_{0}, T_{r, l i m}$ and $\Delta \mathrm{S}^{\circ}$. In absence of data we can use $\mathrm{T}_{0}$ as an initial value of $\mathrm{T}_{\text {lim }}$ for the estimation and prediction by theoretical computing.

It is concluded that this concentration-temperature dependence of the adsorption at equilibrium can also permit comparison between some similar experimental results realized at different temperatures. In addition, it can offer a kind of implicit dependence on temperature of different parameters 
used in various useful isotherm models describing adsorption [25].

\section{Comparison of the highest capability of different} sorbents for $\mathrm{Ni}(\mathrm{II})$ : The removal power of nano-bentonite and other some sorbent materials for exclusion of $\mathrm{Ni}$ (II) presented in literature [26-34] are given in Table-5. It is noted that the sorption ability of nano-bentonite in the direction of $\mathrm{Ni}$ (II) is similar or even superior than another existing sorbents.

\begin{tabular}{lcc}
\multicolumn{3}{c}{ TABLE-5 } \\
COMPARISON OF MAXIMUM ADSORPTION \\
CAPACITY ( $\mathrm{q}_{\text {max }}$ ) OF NANO-BENTONITE AND \\
\multicolumn{1}{c}{ OTHER ADSORBENTS FOR Ni(II) IONS REMOVAL } \\
\hline \multicolumn{1}{c}{ Adsorbent } & $\mathrm{q}_{\max }$ & Ref. \\
\hline Clainedbofebentonite & 3.047 & {$[26]$} \\
Khulays activated bentonite & 47.62 & {$[27]$} \\
Chitosan immobilized on bentonite & 6.1 & {$[28]$} \\
Npp-modified bentonite & 30.30 & {$[29]$} \\
Naturalclay & 1.17 & {$[30]$} \\
Na-bentonite & 24.2 & \\
Ca-bentonite. & 6.3 & {$[31]$} \\
Washed bentonite & 20 & \\
Cleaned bentonite & 22 & {$[32]$} \\
ZrO-montmorillonite & 10.45 & \\
TBA-montmorillonite & 8.50 & {$[33]$} \\
Na-montomorillonite & 7.31 & \\
Peat moss & $32.894\left(65{ }^{\circ} \mathrm{C}\right)$ & {$[34]$} \\
Nano-bentonite & 39.06 & Present study \\
\hline
\end{tabular}

\section{Conclusion}

Nano-bentonite was used in previous work [1] as a sorbent to get rid of nickel ions from aqueous fluids. Outcome revealed that the optimal parameters for the subtraction of nickel ions are primary amount $100 \mathrm{mg} / \mathrm{L}$, sorbent dosage $0.5 \mathrm{~g}$ and $\mathrm{pH} 6$. Nano-bentonite removed nickel with utmost removal capability of $39.06 \mathrm{mg} / \mathrm{g}$ (303.15 K, pH 6). Thermodynamic data designated that sorption process is natural and of an endothermic character.

In the present work we have developed primary and secondary models to illustrate the effect of temperature (from 293.15 to $323.15 \mathrm{~K}$ ) on sorption of $\mathrm{Ni}$ (II) on nano-bentonite. The proposed models can be integrated to estimate some practical specific parameters values for different experimental conditions and can lead to interesting additional interpretations.

In the primary modelling, we have proposed an exponential model on time and linear with absolute temperature to fit the influence of temperature on $\mathrm{Ni}$ (II) concentration, the removal capacity and the thermodynamic variables of $\mathrm{Ni}$ (II) adsorption on nano-bentonite adsorbent.

The secondary modelling is performed through the thermodynamic investigation. We have supposed that the thermodynamic parameters vary slightly with temperature. This original study leads to estimate the variation at equilibrium of $\mathrm{Ni}$ (II) concentration $\left(\mathrm{C}_{\mathrm{e}, \mathrm{T}}\right)$ and the removal capability $\left(\mathrm{q}_{\mathrm{e}, \mathrm{T}}\right)$ against temperature $(\mathrm{T})$.

The suggested semi-empirical equations will permit more interpretation of the studied phenomenon and can lead to predict or estimate some quantities when other are available in literature, or estimate different properties values when parameters of experimental conditions are modified. In addition, the determination of new values of adjustable parameters related to other materials or other experimental conditions can make these parameters an interesting criterion of discussion and prediction. Furthermore, any find of eventual causal correlation between the adjustable parameters can generate future interesting theoretical novel concepts or more expanded existing theories. Moreover, this novel investigation could be patterned by the practice of these suggested equations to be readjusted to other experimental conditions, with specific interpretation of the new obtained free adjustable equations' parameters.

\section{REFERENCES}

1. A.A. Taha, A.M. Ahmed, H.H. Abdel Rahman, F.M. Abouzeid and M.O. Abdel Maksoud, J. Dispers. Sci. Technol., 38, 757 (2017); https://doi.org/10.1080/01932691.2016.1194211.

2. A.H.M. Veeken and H.V.M. Hamelers, Water Sci. Technol., 40, 129 (1999); https://doi.org/10.1016/S0273-1223(99)00373-X.

3. S.A. Sadeek, N.A. Negm, H.H.H. Hefni and M.M. Abdel Wahab, Int. J. Biol. Macromol., 81, 400 (2015); https://doi.org/10.1016/j.ijbiomac.2015.08.031.

4. Y. Zhou, Z. Zhang, J. Zhang and S. Xia, J. Environ. Sci., 45, 248 (2016); https://doi:10.1016/j.jes.2016.03.007.

5. A. Dabrowski, Z. Hubicki, P. Podkoscielny and E. Robens, Chemosphere, 56, 91 (2004); https://doi.org/10.1016/j.chemosphere.2004.03.006.

6. Z.-Y. Yao, J.-H. Qi and L.-H. Wang, J. Hazard. Mater, 174, 137 (2010); https://doi.org/10.1016/j.jhazmat.2009.09.027.

7. N. Rangsayatorn, P. Pokethitiyook, E.S. Upatham and G.R. Lanza, Environ. Int., 30, 57 (2004); https://doi:10.1016/S0160-4120(03)00146-6.

8. N. Meunier, J. Laroulandie, J.F. Blais and R.D. Tyagi, Bioresour. Technol., 90, 255 (2003);

https://doi.org/10.1016/S0960-8524(03)00129-9.

9. G. Yan and T. Viraraghavan, Bioresour. Technol., 78, 243 (2001); https://doi.org/10.1016/S0960-8524(01)00020-7.

10. U. Farooq, J.A. Kozinski, M.A. Khan and M. Athar, Bioresour. Technol., 101, 5043 (2010); https://doi.org/10.1016/j.biortech.2010.02.030

11. B.K. Reck, D.B. Müller, K. Rostkowski and T.E. Graedel, Environ. Sci. Technol., 42, 3394 (2008); https://doi:10.1021/es0721081.

12. A. Perosa and P. Tundo, Ind. Eng. Chem. Res., 44, 8535 (2005); https://doi:10.1021/ie0489251.

13. A.K. Shukla, S. Venugopalan and B. Hariprakash, J. Power Sources, 100, 125 (2001); https://doi.org/10.1016/S0378-7753(01)00890-4.

14. E. Denkhaus and K. Salnikow, Crit. Rev. Oncol. Hematol., 42, 35 (2002); https://doi.org/10.1016/S1040-8428(01)00214-1.

15. K.S. Kasprzak, F.W. Sunderman and K. Salnikow, Mutat. Res., 533, 67 (2003); https://doi.org/10.1016/j.mrfmmm.2003.08.021.

16. M. Cempel and G. Nikel, Pol. J. Environ. Stud., 15, 375 (2006);

17. J.J.M. Orfao, A.I.M. Silva, J.C.V. Pereira, S.A. Barata, I.M. Fonseca, P.C.C. Faria and M.F.R. Pereira, J. Colloid Interface Sci., 296, 480 (2006); https://doi.org/10.1016/j.jcis.2005.09.063.

18. S. Hashemian, Asian J. Chem., 21, 3622 (2009).

19. S. Ben-Ali, I. Jaouali, S. Souissi-Najar and A. Ouederni, J. Clean. Prod., 142, 3809 (2017); https://doi.org/10.1016/j.jclepro.2016.10.081.

20. A.S. Özcan and A. Özcan, J. Colloid Interface Sci., 276, 39 (2004); https://doi.org/10.1016/j.jcis.2004.03.043.

21. A.S. Özcan, O. Gok and A. Özcan, J. Hazard. Mater, 161, 499 (2009); https://doi.org/10.1016/j.jhazmat.2008.04.002.

22. R. Naseem and S.S. Tahir, Water Res., 35, 3982 (2001); https://doi.org/10.1016/S0043-1354(01)00130-0.

23. Z.N. Garba and A.A. Rahim, Process Saf. Environ. Prot., 102, 54 (2016); https://doi.org/10.1016/j.psep.2016.02.006. 
24. H. Singh, G. Chauhan, A.K. Jain and S.K. Sharma, J. Environ. Chem. Eng., 5, 122 (2017); https://doi.org/10.1016/j.jece.2016.11.030.

25. N. Ayawei, A.N. Ebelegi and D. Wankasi, J. Chem., Article ID 3039817 (2017);

https://doi.org/10.1155/2017/3039817.

26. M.G.A. Vieira, A.F. Almeida-Neto, M.L. Gimenes and M.G.C. da Silva, J. Hazard. Mater., 177, 362 (2010); https://doi.org/10.1016/j.jhazmat.2009.12.040.

27. S.S. Al-Shahrani, Int. J. Eng. Technol., 12, 14 (2012).

28. C.M. Futalan, W.-C. Tsai, S.-S. Lin, K.-J. Hsien, M.L. Dalida and M.-W. Wan, Sustain. Environ. Res., 22, 345, (2012).

29. B.N. Sandeep and S. Suresha, Int. J. Environ. Sci., 4, 113 (2013); https://doi:10.6088/ijes.2013040100012.
30. M.G. Bhagyalakshmi and P.N. Sarma, J. Chem. Pharm. Res., 7, 140 (2015);

31. E. Alvarez-Ayo, A. Garcia-Sanchez and X. Queol, Water Res., 37, 4885 (2003); https://doi.org/10.1016/j.watres.2003.08.009.

32. N.M. Alandis, O.A. Aldaye, W.K. Mekhemer, J.A. Hefne and H.A. Jakhob, J. Dispers. Sci. Technol., 31, 1526 (2010); https://doi.org/10.1080/01932690903294097.

33. M.-H. Baek and C.O. Ljabemi, J. Hazard. Mater, 176, 820 (2010); https://doi.org/10.1016/j.jhazmat.2009.11.110.

34. L. Bulgariu, D. Bulgariu and M. Macoveanu, Environ. Eng. Manage. J., 9, 667 (2010). 